\title{
Effect of butylated hydroxytoluene supplementation on ultrastructure of crossbred bovine spermatozoa
}

\author{
M Sharma and A Singh
}

Received: 12 May 2019 / Accepted: 23 July 2019 / Published online: 28 October 2019

(C) Indian Dairy Association (India) 2019

\begin{abstract}
The present study was planned to observe the effect of Butylated hydroxytoluene (BHT) on ultra structure changes in crossbred bull spermatozoa. The sperm plasma membrane is the primary site of damage induced by cryopreservation. There are many harmful conditions such as cold shock, osmotic stress, ice crystal formation or oxidative damage etc. which cause sperm cryo-injury and loss of sperm viability and fertility during cryopreservation. At the time of cryopreservation there were considerable ultra structure changes to the acrosome and middle piece studied by transmission electron microscopy. Semen from two crossbred bulls were collected and extended with egg yolk tris dilutor along with addition of different concentrations of BHT i.e. without BHT (Control), $0.5 \mathrm{mM}\left(\mathrm{T}_{1}\right)$ and $1.0 \mathrm{mM}\left(\mathrm{T}_{2}\right)$, respectively. The effect of BHT on ultrastructural alterations was revealed by Transmission electron microscopy during post dilution (Stage I), post equilibration (Stage II) and post thaw (Stage III), respectively. TEM results of spermatozoa at Stage I, II and III showed that major ultrastrucural alterations occur in plasma membrane and outer acrosomal membrane. Group $\mathrm{T}_{1}$ and $\mathrm{T}_{2}$ showed significantly lower number of ultrastructural defects as compared to control at Stage I, II and III. The study indicated that $1.0 \mathrm{mM}$ BHT in egg yolk tris dilutor increases the cryosurvival of sperm as revealed by post thaw lower ultrastructural defects of crossbred bull spermatozoa.
\end{abstract}

M Sharma and A Singh

Department of Veterinary Gynaecology and Obstetrics

College of Veterinary and Animal Sciences, G.B Pant University of Agriculture and Technology, Pantnagar-263145, Uttarakhand, India

Mridula Sharma ( $\triangle)$

Veterinary Gynaecology, CVASc, GBPUA\&T., Pantngar, Uttarakhand, India

E-mail: sharmavetmridula@yahoo.co.in
Keywords: BHT, Crossbred bull sperm, Cryopreservation, Transmission electron microscopy, Ultrastructure,

\section{Introduction}

Cryopreservation is detrimental to sperm function and fertility even if we use the most up to date technique. Sperm viability and fertility is decreased by about $50 \%$ after cryopreservation (Lessard et al. 2000). There are many harmful conditions such as cold shock, osmotic stress, ice crystal formation or oxidative damage etc which cause sperm cryoinjury and loss of sperm viability and fertility (Amirat et al. 2014, Li et al. 2005, Asadpour et al. 2012, Bucack et al. 2010). The characteristic feature of biological cell membrane is the asymmetrical arrangement of phospholipids bilayer with cholesterol, complex carbohydrate and protein. Sperm cells consist of a high amount of polyunsaturated fatty acids (PUFA) which makes the membranes more susceptible to oxidative damage by ROS. At the time of cryopreservation there were considerable ultrastructural changes to the acrosomes and middle piece studied by transmission electron microscopy (TEM) (Pesch et al. 1989, Jones and stewart, 1979; Krogenase et al. 1994; Lopez Armengol et al. 2012; Kumar, 2012; Khan et al. 2015). Changes in acrosome include breakage of the plasma and outer acrosomal membranes and efflux of the acrosomal contents. Changes in middle piece include breakage of the plasma membrane, irregular mitochondrial helix.

Improved understanding the causes of the cryoinjury is important to improve the efficiency of semen cryopreservation (Watson, 1995). In the past years, a series of functional assays have been developed to determine the structural morphology and functional integrity of the plasma membrane and sperm acrosomal membrane (Tartaglionea and Ritta, 2004). Morphological classification of sperm has become an integral part of the modern semen analysis, particularly an important indicator of fertility. Sperm morphology has been reported as the most prognostic factor in determining the outcome of in vitro fertilization, more significant than other conventional semen analysis parameters, including sperm concentration and fertility (Yue et al. 1995). The plasma membrane and the acrosome membrane are the most sensitive parts of the sperm (Krogenase et al. 1994). The outer acrosome membrane is more vulnerable than the inner parts and the internal membrane. 
Sperm head is composed of nucleus surrounded by a cytoplasmic layer containing an apical body, the acrosome and the head cap. The complete head is ensheathed within a plasma membrane.

Butylated hydroxytoluene (BHT) also known as butylhydroxytoluene, an artificial antioxidant is a lipophilic (fatsoluble) organic compound and has an excellent antioxidant capacity (Merino et al. 2015). It is chemically a derivative of phenol hence used as antioxidant. It behaves as a synthetic analogue of vitamin E. It was primarily acting as terminating agent that suppresses autoxidation, which is a process where unsaturated (usually) organic compounds are targeted by atmospheric oxygen. BHT stops this autocatalytic reaction by converting peroxy radicals to hydroperoxides (Patel et al. 2015). Lipid solubility is a unique property of BHT due to which it acts as an antioxidant within and outside the sperm membrane.

Thus, the present study was planned to observe the effect of Butylated hydroxytoluene (BHT) on post thaw ultrastructure changes of crossbred bull spermatozoa by electron microscopy.

\section{Materials and Methods}

\section{Source of semen sample}

Two crossbred bulls ( $1 / 2$ HF x $1 / 2 \mathrm{~J})$ of aged 4- 6 years weighing 450-500 Kg, reared at Semen Production Centre, Department of Veterinary Gynaecology \& Obstetrics, College of Veterinary and Animal Sciences, G. B. Pant University of Agriculture and Technology, Pantnagar, Uttarakhand-263145, India were selected for the study. The bulls were kept under identical feeding and managemental conditions. Study carried out from December to March month and 2-3 ejaculates/week were collected by artificial vaginal method during morning time. Ethical approval for the planned study has been taken.

\section{Initial evaluation of semen sample}

The fresh semen samples collected from two crossbred bulls were evaluated for volume, $\mathrm{pH}$, mass motility and sperm concentration. For uniformity ejaculate with mass activity of + $3.0(0-5.0$ scale $)$ and a progressive motility of $70 \%$ or more were selected for the study.

\section{Preparation of 0.5 and $1.0 \mathrm{mM}$ BHT solution and extension of semen}

Dissolution of $275.44 \mathrm{mg}$ BHT (SRL, India) in $25 \mathrm{ml}$ of ethanol was done for making a BHT concentration of $0.05 \mathrm{~mole} / \mathrm{ml}$. Then this solution was added in the two glass test tubes@0.05 and $0.1 \mathrm{ml}$ and kept them for few minutes at $37^{\circ} \mathrm{C}$ in an incubator so that ethanol containing BHT was then evaporated resulting in sticking of BHT in the inner wall of the test tubes. The semen was extended with glycerolated egg yolk tris (EYT) extender as per need. To each of this test tubes $5 \mathrm{ml}$ of extended semen was added making a concentration of $0.5 \mathrm{mM} \mathrm{BHT}\left(\mathrm{T}_{1}\right)$ and $1.0 \mathrm{mM}$ $\mathrm{BHT}\left(\mathrm{T}_{2}\right)$. The extended semen along with BHT was then kept at $37^{\circ} \mathrm{C}$ for $5 \mathrm{~min}$ to allow uptake of BHT by spermatozoa. Simultaneously, the same amount of extended semen was kept in another test tube (without BHT) and considered as control.

\section{Sample preparation for transmission electron microscopy (TEM)}

Electron microscopy was performed at three stages i.e., after dilution (Stage I), post equilibration (Stage II) and post thaw (Stage III) to study the effect of BHT on structural properties of spermatozoa. $1 \mathrm{ml}$ of semen from each group and stage was taken into a $5 \mathrm{ml}$ eppendrof tube and immediately fixed by addition of $0.5 \mathrm{ml}$ of Karnovsky's fixative (2.5\% gluteraldehyde and $2 \%$ parafarmaldehyde in PBS). After fixation, samples were kept for 4 hours at $4^{\circ} \mathrm{C}$ and subsequently washed two times with PBS by gentle centrifugation ( $170 \mathrm{~g} \times 10 \mathrm{~min}$ each) at $4^{\circ} \mathrm{C}$. A second fixation was performed with $1 \%$ osmium tetraoxide solution $\left(\mathrm{OsO}_{4}\right)$ in 0.1 M PBS for $1 \mathrm{~h}$ at $4^{\circ} \mathrm{C}$ and then washed again in PBS twice for 10 min. each. The samples were dehydrated in a graded ethanol series $(50 \%, 70 \%, 80 \%, 95 \%$ and $100 \%$ ethanol) for $10 \mathrm{~min}$. in each solution. Clearing of samples was done by toluene for 30 min. For block preparation, spermatozoa were infiltrated with epoxy resin overnight and embedded in fresh epoxy resin and placed into an oven at $60^{\circ} \mathrm{C}$ for $12 \mathrm{~h}$. The blocks were then sectioned using an Ultra Cut (UCT Leica Ultra-microtome) at 60$80 \mathrm{~nm}$ width with a glass knife and mounted onto copper grids and stained with drops of $2 \%$ uranyl acetate, followed by lead citrate for 1-2 min. Sperms were examined with a FEI Tecnai G220 $\mathrm{S}$ - Twin (Holland) transmission electron microscope $(80 \mathrm{kv})$ at Sophisticated Advanced Instrument Facility (SAIF) AIIMS, New Delhi, India.

\section{Results and Discussion}

Spermatozoa heads with dilated plasma membranes were significantly $(\mathrm{p}<0.05)$ lower in $\mathrm{T}_{2}$ as compared to control and $\mathrm{T}_{1}$ after dilution (Stage $\mathrm{I}) \mathrm{T}_{1}$ also showed significantly $(\mathrm{p}<0.05)$ lower percentage of dilated plasma membranes as compared to control (Table 1, Fig. 1 to 6). Percentage of dilated plasma membrane and outer acrosomal membrane were significantly $(\mathrm{p}<0.05)$ lower in $\mathrm{T}_{2}$ as compared to other groups The percentage of broken plasma membrane and outer acrosomal membrane were significantly $(\mathrm{p}<0.05)$ lower in $\mathrm{T}_{2} . \mathrm{T}_{1}$ also showed significantly $(\mathrm{p}<0.05)$ lower number of defects as compared to control.

After equilibration (Stage II), spermatozoa head with dilated plasma membranes were significantly $(\mathrm{p}<0.05)$ lower in $\mathrm{T}_{2}$ as compared to control and $\mathrm{T}_{1}$. Some of the sperm heads also showed dilated acrosomal membrane. Dilated plasma membrane and outer acrosomal membrane were significantly $(\mathrm{p}<0.05)$ lower in $\mathrm{T}_{2}$ as compared to control and $\mathrm{T}_{1}$. Also broken plasma membrane and outer acrosomal membrane were significantly $(\mathrm{p}<0.05)$ lower in $\mathrm{T}_{2}$ as compared to control and $\mathrm{T}_{1}$. $\mathrm{T}_{1}$ also had significantly 
Fig. 1 Transmission electron microphotograph of longitudinal section of head showing dilated plasma membrane (white arrow), longitudinal and transverse section of midpiece showing closely apposed plasma membrane (black arrow) of bovine bull spermatozoa (X 25000)

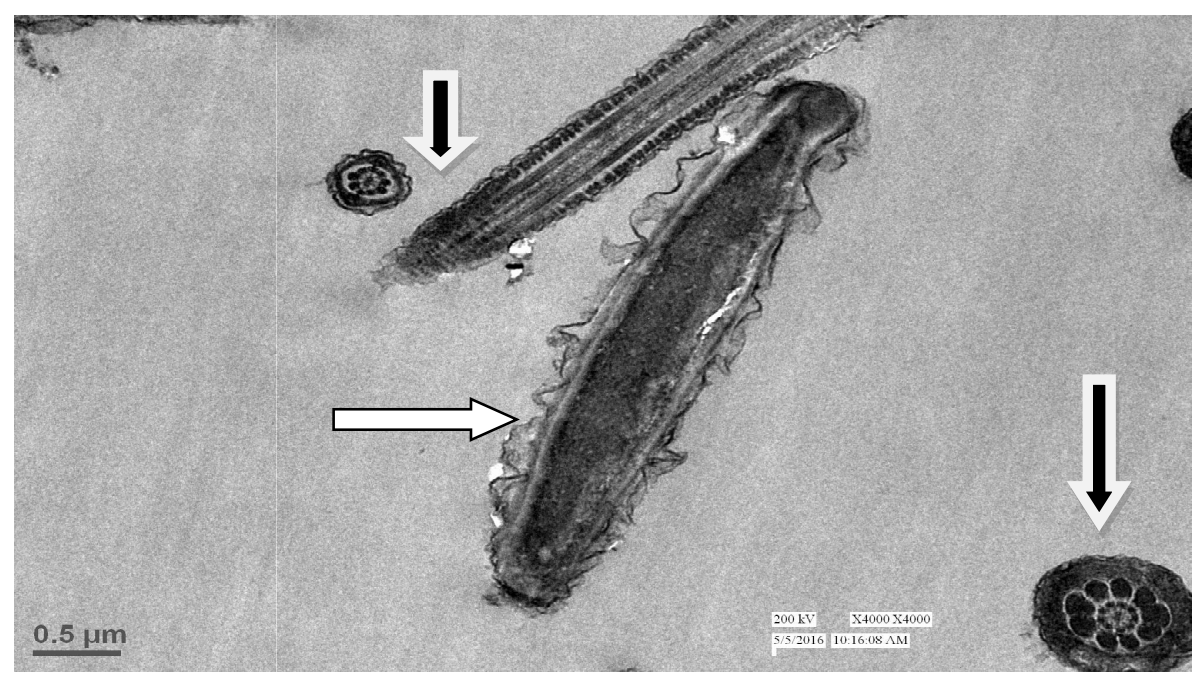

Table 1 Effect of BHT on ultrastructure of crossbred bull spermatozoa at stage I (Post dilution)

\begin{tabular}{|c|c|c|c|c|c|}
\hline \multirow[t]{2}{*}{ Groups } & \multicolumn{3}{|l|}{ Sperm head } & \multirow{2}{*}{$\begin{array}{l}\text { Longitudinal } \\
\text { section of sperm } \\
\text { midpiece } \\
\text { Irregular } \\
\text { mitochondrial } \\
\text { helix }\end{array}$} & \multirow{2}{*}{$\begin{array}{c}\text { Transeverse section of } \\
\text { sperm midpiece }\end{array}$} \\
\hline & $\begin{array}{l}\text { Dilated plasma } \\
\text { membrane }\end{array}$ & $\begin{array}{l}\text { Dilated plasma } \\
\text { membrane and } \\
\text { outer acrosomal } \\
\text { membrane }\end{array}$ & $\begin{array}{l}\text { Broken plasma } \\
\text { membrane and } \\
\text { outer acrosomal } \\
\text { membrane }\end{array}$ & & \\
\hline$\overline{\mathrm{T}_{1}}$ & $\begin{array}{l}5^{b}(4.13 \%) \\
(n=121)\end{array}$ & $\begin{array}{l}3^{b}(2.47 \%) \\
(n=121)\end{array}$ & $\begin{array}{l}1^{\mathrm{b}}(0.82 \%) \\
(\mathrm{n}=121)\end{array}$ & $0(\mathrm{n}=73)$ & $0(\mathrm{n}=129)$ \\
\hline $\mathrm{T}_{2}$ & $\begin{array}{l}2^{\mathrm{c}}(1.69 \%) \\
(\mathrm{n}=118)\end{array}$ & $\begin{array}{l}1^{\mathrm{c}}(0.84 \%) \\
(\mathrm{n}=118)\end{array}$ & $0^{c}(\mathrm{n}=118)$ & $0(\mathrm{n}=66)$ & $0(n=133)$ \\
\hline Control & $\begin{array}{l}8^{a}(5.8 \%) \\
n=138\end{array}$ & $\begin{array}{l}5^{\mathrm{a}}(3.62 \%) \\
(\mathrm{n}=138)\end{array}$ & $\begin{array}{l}3^{\mathrm{a}}(2.17 \%) \\
(\mathrm{n}=138)\end{array}$ & $0(\mathrm{n}=69)$ & $0(\mathrm{n}=124)$ \\
\hline
\end{tabular}

Means bearing different superscript $(a, b, c)$ in a column differ significantly $(p<0.05)$

$\mathrm{n}=$ number of sperms observed under electron microscope

$(\mathrm{p}<0.05)$ lower number of all type of defects as compared to control (Table 2, Fig. 1 to 6).

At post thaw stage, sperms with dilated plasma membrane were significantly $(\mathrm{p}<0.05)$ lower than other groups. More damages of sperm were observed in post thaw stage semen. Spermatozoa with dilated plasma membrane and outer acrosomal membrane were significantly $(\mathrm{p}<0.05)$ more in control $(10 \%)$ as compared to $\mathrm{T}_{1}(7.2 \%)$ and $\mathrm{T}_{2}(4.1 \%) . \mathrm{T}_{2}$ showed significantly $(\mathrm{p}<0.05)$ lower number of all ultra structural defect than control and $\mathrm{T}_{1}$ (table 3 , Fig. 1 to 6). At stage III, longitudinal section of midpiece revealed less number of spermatozoa with irregular arrangement of mitochondria in BHT treated groups. Irregular mitochondrial helix was significantly $(\mathrm{p}<0.05)$ higher in control $(15.94 \%)$ than $\mathrm{T}_{1}$ (11.68) and $\mathrm{T}_{2}(8.43 \%)$. Transverse section of midpiece showed significantly $(\mathrm{p}<0.05)$ higher no. of dilated plasma membrane in control $(12.76 \%)$ as compared to $\mathrm{T}_{1}(10.22 \%)$ and $\mathrm{T}_{2}(8.69 \%)$. Axonemal displacement was not seen in control and BHT treated groups.
The present study indicated that plasma membrane of most of the freshly diluted spermatozoa were intact (close opposition to inner structure). Outer and inner acrosomal membranes were also intact without any damage. Similarly, in the fresh semen, longitudinal section of midpiece showed regular arrangement of mitochondria and covered by plasma membrane (Luque and Bao, 2006). Also, transverse section of midpiece showed regular arrangement of axoneme. Where as fresh buffalo semen evaluation, there were $98.13 \%$ sperm with intact plasma membrane and acrosomal membrane. However, $2.34 \%$ of sperm head showed dilated plasma membrane and $2.80 \%$ showed dilation of plasma membrane and outer acrosomal membrane (Kumar, 2012). In the contrary, $70 \%$ sperm heads with normal acrosome were observed in undiluted fresh semen and it was non-significantly decreased on dilulion (60\%) i.e. $40 \%$ sperm have abnormal acrosome (Kakar and Anand, 1984).

The percentage of heads with dilated plasma membrane was significantly $(\mathrm{p}<0.05)$ higher in control group as compared to 
Fig. 2 Transmission electron microphotograph of longitudinal section of midpiece showing irregular arrangement of mitochondria (black line) of crossbred bull spermatozoa (X 49000)

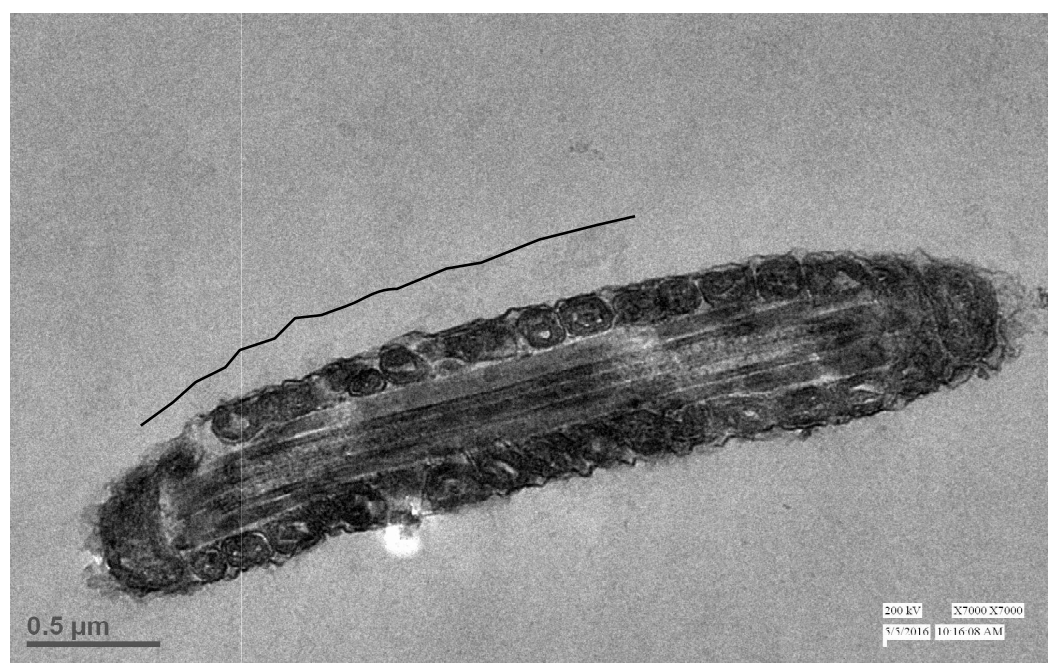

Fig. 3 Transmission electron microphotograph of longitudinal section of head showing dilation of plasma membrane (white arrow) over acrosome (red arrow) of crossbred bull spermatozoa (X 64000)

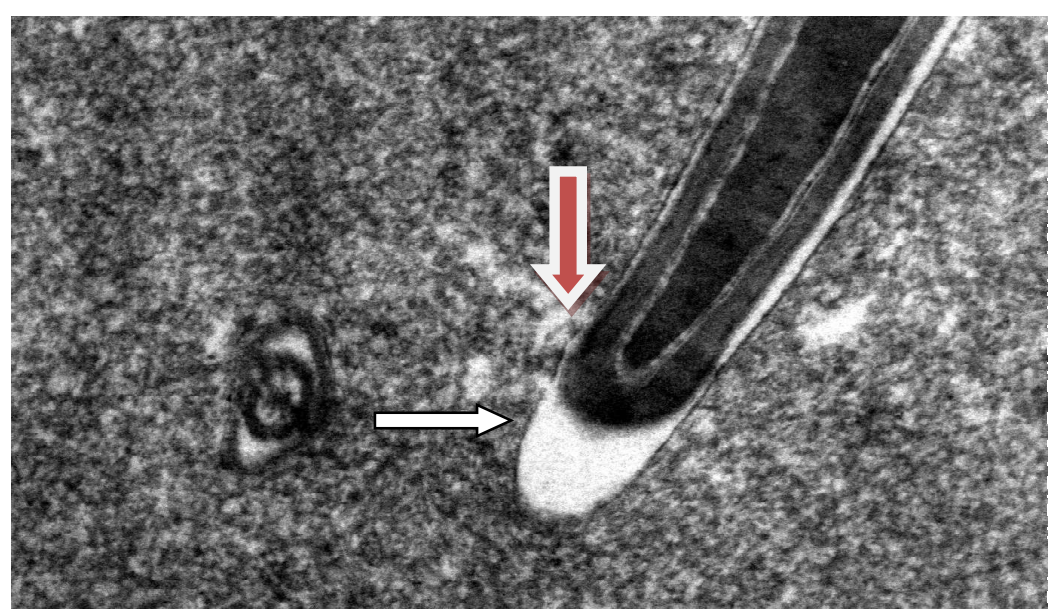

Table 2 Effect of BHT on ultrastructure of crossbred bull spermatozoa at stage II (Post equilibration)

\begin{tabular}{|c|c|c|c|c|c|}
\hline$\overline{\text { Group }}$ & \multicolumn{3}{|l|}{ Sperm head } & $\begin{array}{l}\text { Longitudinal } \\
\text { section of } \\
\text { sperm midpiece } \\
\text { Irregular } \\
\text { mitochondrial } \\
\text { helix }\end{array}$ & $\begin{array}{c}\text { Transeverse section of } \\
\text { sperm midpiece } \\
\text { Axonemal } \\
\text { displacement/vacuole }\end{array}$ \\
\hline$\overline{\mathrm{T}_{1}}$ & $\begin{array}{l}19^{\mathrm{b}}(21.5 \%) \\
(\mathrm{n}=88)\end{array}$ & $\begin{array}{l}4^{b}(4.55 \%) \\
(n=88)\end{array}$ & $\begin{array}{l}4^{b}(4.54 \%) \\
(n=88)\end{array}$ & $\begin{array}{l}0 \\
(n=71)\end{array}$ & $\begin{array}{c}0 \\
(n=102)\end{array}$ \\
\hline $\mathrm{T}_{2}$ & $\begin{array}{l}13^{\mathrm{c}}(12.5 \%) \\
(\mathrm{n}=104)\end{array}$ & $\begin{array}{l}3^{c}(2.8 \%) \\
(n=104)\end{array}$ & $\begin{array}{l}2^{c}(1.92 \%) \\
(n=104)\end{array}$ & $\begin{array}{l}0 \\
(n=76)\end{array}$ & $\begin{array}{c}0 \\
(\mathrm{n}=112)\end{array}$ \\
\hline Control & $\begin{array}{l}24^{\mathrm{a}}(24.49 \%) \\
(\mathrm{n}=98)\end{array}$ & $\begin{array}{l}10^{\mathrm{a}}(10.2 \%) \\
(\mathrm{n}=98)\end{array}$ & $\begin{array}{l}5^{\mathrm{a}}(5.10 \%) \\
(\mathrm{n}=98)\end{array}$ & $\begin{array}{l}0 \\
(n=75)\end{array}$ & $\begin{array}{c}0 \\
(n=82)\end{array}$ \\
\hline
\end{tabular}

Means bearing different superscript $(a, b, c)$ in a column differ significantly $(\mathrm{p}<0.05)$

BHT treated groups. The percentage of spermatozoa with dilated plasma membrane and outer acrosomal membrane significantly $(\mathrm{p}<0.05)$ differed between control and BHT treated groups. There was also significantly $(\mathrm{p}<0.05)$ less percentage of sperm heads with broken plasma membrane and outer acrosomal membrane in treated $\left(\mathrm{T}_{1}\right.$ and $\left.\mathrm{T}_{2}\right)$ groups than control group. There were no 
Fig.4 Transmission electron microphotograph of longitudinal section of head showing broken plasma membrane and acrosome membrane (white arrow) of crossbred bull spermatozoa (X 49000)

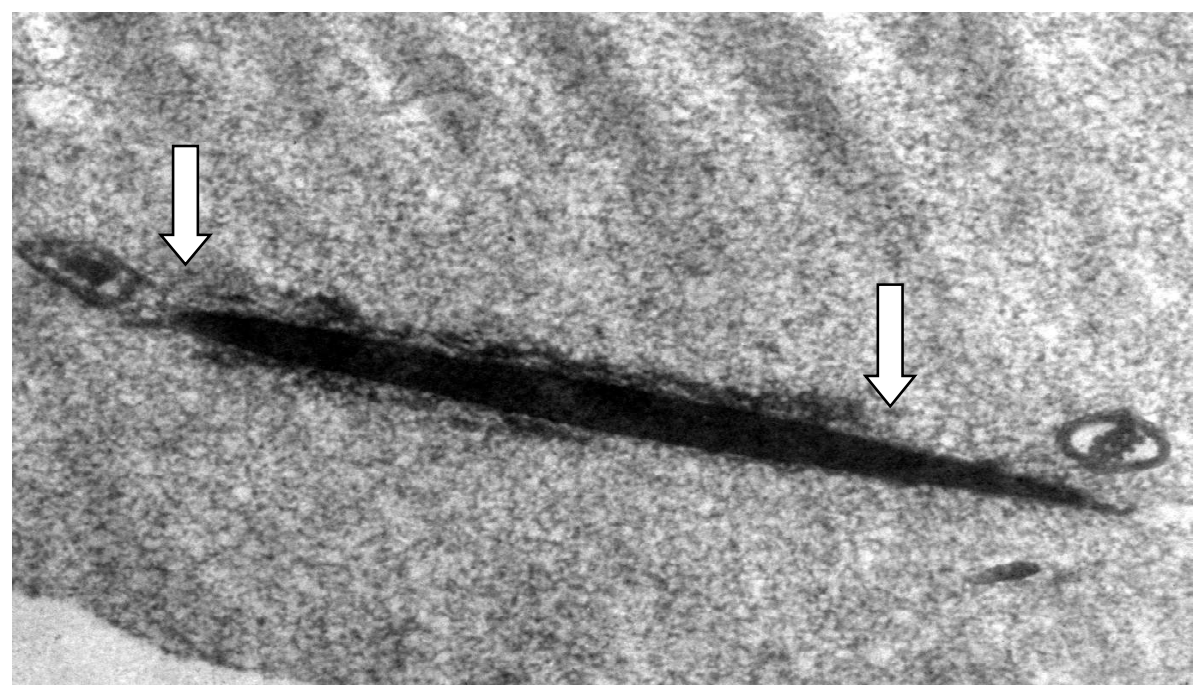

Fig. 5 Transmission electron microphotograph of longitudinal section of head showing dilated plasma membrane (white arrow) and acrosome membrane (blue arrow) of crossbred bull spermatozoa $\mathrm{X}$ 25000

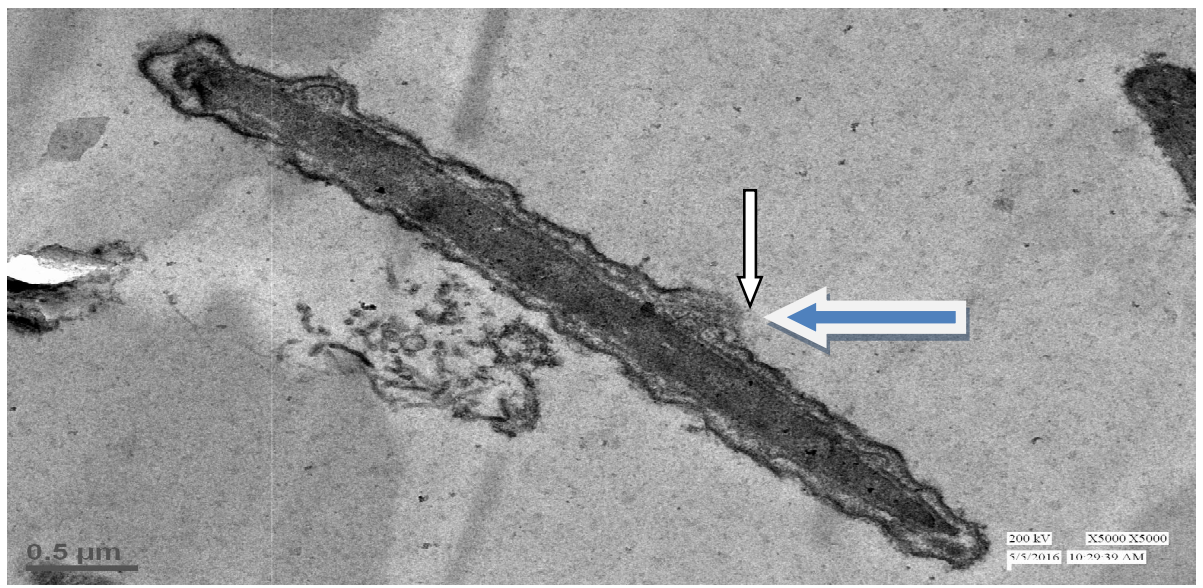

Table 3 Effect of BHT on ultrastructure of crossbred bull spermatozoa at stage III (Post thaw)

\begin{tabular}{|c|c|c|c|c|c|c|}
\hline Group & \multicolumn{3}{|c|}{ Sperm head } & $\begin{array}{l}\text { Longitudinal } \\
\text { section of } \\
\text { sperm midpiece } \\
\text { Irregular } \\
\text { mitochondrial } \\
\text { helix }\end{array}$ & \multicolumn{2}{|l|}{$\begin{array}{l}\text { Transeverse } \\
\text { section of } \\
\text { sperm midpiece }\end{array}$} \\
\hline $\mathrm{T}_{1}$ & $\begin{array}{l}39^{\mathrm{b}}(40.20 \%) \\
(\mathrm{n}=97)\end{array}$ & $\begin{array}{l}9^{b}(7.2 \%) \\
(n=97)\end{array}$ & $\begin{array}{l}4^{b}(4.12 \%) \\
(n=97)\end{array}$ & $\begin{array}{l}9^{b}(11.68 \%) \\
(n=77)\end{array}$ & $\begin{aligned} & 9^{\mathrm{b}}(10.22 \%) \\
\mathrm{n} & =88\end{aligned}$ & $\begin{array}{c}0 \\
(n=91)\end{array}$ \\
\hline $\mathrm{T}_{2}$ & $\begin{array}{l}26^{c}(35.61 \%) \\
(n=73)\end{array}$ & $\begin{array}{l}4^{c}(4.1 \%) \\
(n=73)\end{array}$ & $\begin{array}{l}2^{c}(2.7 \%) \\
(n=73)\end{array}$ & $\begin{array}{l}7^{\mathrm{b}}(8.43 \%) \\
(\mathrm{n}=83)\end{array}$ & $\begin{array}{l}8^{\mathrm{b}}(8.69 \%) \\
\mathrm{n}=92\end{array}$ & $\begin{array}{c}0 \\
(n=94)\end{array}$ \\
\hline control & $\begin{array}{l}52^{\mathrm{a}}(47.27 \%) \\
(\mathrm{n}=110)\end{array}$ & $\begin{array}{l}16^{\mathrm{a}}(10 \%) \\
(\mathrm{n}=110)\end{array}$ & $\begin{array}{l}8^{a}(7.27 \%) \\
(n=110)\end{array}$ & $\begin{array}{l}11^{a}(15.94 \%) \\
(n=69)\end{array}$ & $\begin{aligned} & 12^{\mathrm{a}}(12.76 \%) \\
\mathrm{n} & =94\end{aligned}$ & $\begin{array}{c}0 \\
(n=81)\end{array}$ \\
\hline
\end{tabular}

Means bearing different superscript $(a, b, c)$ in a column differ significantly $(p<0.05)$

detectable changes observed in mitochondria and axonemal complex of midpiece in longitudinal and transverse section of sperm, respectively, after equilibration in all groups. The effect of BHT on plasma membrane dilation were in agreement with 
Fig. 6 Transmission electron microphotograph of longitudinal section of head showing broken plasma membrane and acrosome membrane (white arrow) of bovine bull spermatozoa X 56250

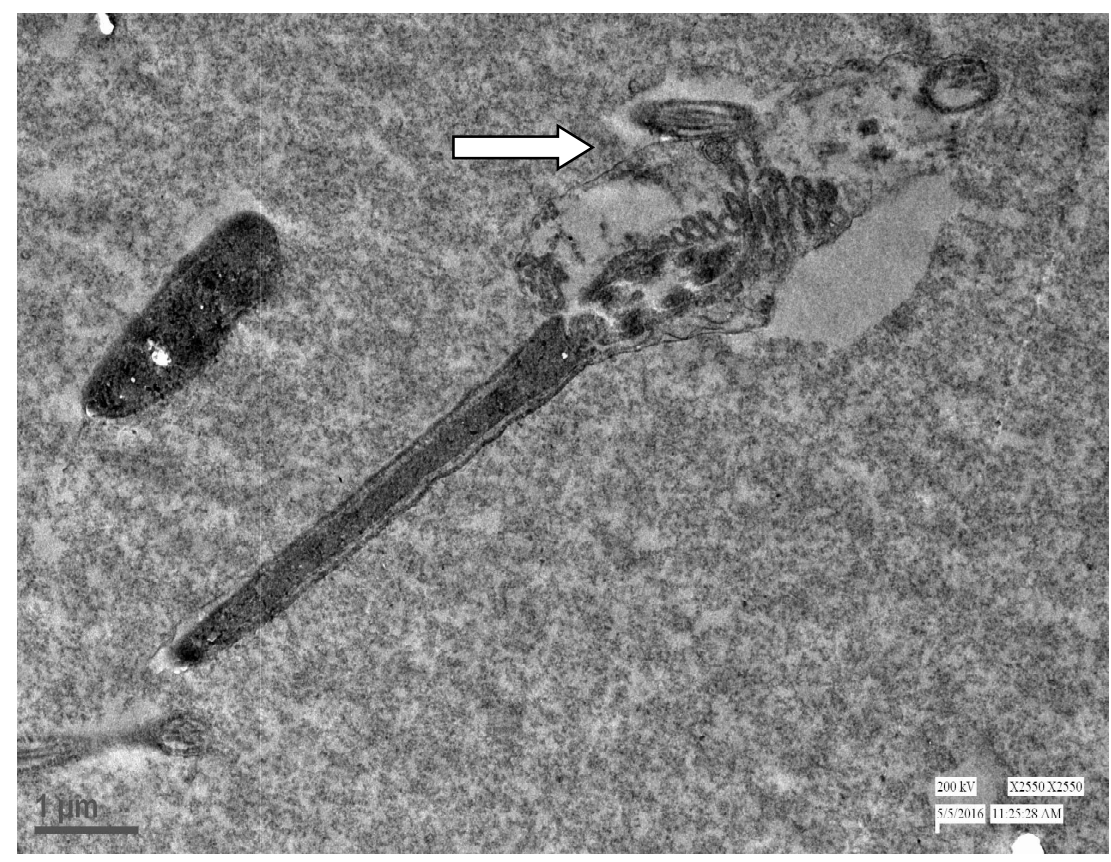

earlier study as ultrastructure of spermatozoa in CLC (cryoprotectent) added semen after equilibration was assessed and significantly $(\mathrm{p}<0.05)$ lower number of dilated plasma membrane (15.46\%) were observed than control (33.77\%) group (Kumar, 2012). BHT showed its protective action in protection membrane and organelles of bovine sperm (Sharma and Singh 2019).

Our observations also confirm that the most negative effect of cold shock and freezing was on the acrosome and plasma membrane of spermatozoa (Lopez Armengol et al. 2012; Kumar, 2012; Khan et al. 2015). Only few sperm showed irregular mitochondrial helix after freezing. An alteration of the mitochondrial sheath was observed after freeze-thawing. However, axoneme with its tail filament and fibrils showed no detectable changes after cryopreservation. Ultrastucture damage is always accompanied by biochemical changes or even loss of their vital contents (Salamon and Maxwell, 1995). The damaging effects of freeze-thawing were more pronounced in control group as compared to BHT treated groups. Although there is no report in the literature related to ultrastructural changes after BHT addition in dilutor. But in buffalo semen, addition of $2 \mathrm{mg}$ CLC (Cholesterol loaded cyclodextrin) resulted significantly $(p<0.05)$ lower number of dilated plasma membrane and outer acrosomal membrane $(2.90 \%)$ than control $(12.5 \%)$ at post thaw stage (Kumar, 2012). In another study (Kakar and Anand, 1984) ultrastructure of buffalo spermatozoa at post thaw stages was performed by TEM. They showed significantly $(\mathrm{P}<0.01)$ decrease the number of sperm head with normal acrosome on freezing and thawing $(23 \%)$ as compared to fresh $(70 \%)$ and diluted semen $(60 \%)$. The ultrastructural changes observed were swelling of acrosomes, vesiculation, vaculation, loss of acrosome and breakage or complete loss of plasma membrane. Present observation is comparable with findings of earlier workers in buffalo spermatozoa (Kakar and Anand, 1984;).

The minimum alterations in sperm ultrastructure in BHT treated groups were observed as BHT stabilized the membrane, reduced membrane permeability and resistant to osmotic pressure change which occur during the freeze-thawing process (Hammerstedt et al. 1990). The BHT treated groups preserved the integrity of plasma and acrosomal membrane more efficiently than control.

\section{Conclusions}

Beneficial effects of BHT addition on semen preservation was observed as ultrastructural findings of spermatozoa supported the protective action of BHT as it reduced the damage of membrane and organelles of bovine spermatozoa.

\section{Acknowledgments}

The authors are highly thankful to Dean, College of Veterinary and Animal Sciences and Vice Chancellor of G.B Pant University of Agriculture and Technology, Pantnagar-263 145, Uttarakhand, India for providing necessary facilities and financial support for carrying out the MVSc. research work of first author.

\section{References}

Amirat L, Tainturier D, Jeanneau L, Thorin C, Gerard O, Courtens JL, Anton M (2004) Bull semen in vitro fertility after cryopreservation using egg yolk LDL: a comparison with optidyl, a commercial egg yolk extender. Theriogenology 61: 895-907

Asadpour R, Jafari R, Tayefi-Nasrabadi H (2012) The effect ofantioxidant supplementation in semen extenders on semen qualityand lipid peroxidation of chilled bull spermatozoa. Iran J Vet Res13: 246249 
Bucak MN, Sariozkan S, Tuncer PB (2010) The effect of antioxidants on post-thawed Angora goat (Capra hircus ancryrensis) sperm parameters, lipid peroxidation and antioxidant activities. Small Rumin Res 89: $24-30$

Hammerstedt RH, Graham JK, Nolan JP (1990) Cryopreservation of mammalian sperm: what we ask them to survive. J Androl 11: 7388

Jones RC, Stewart DL (1979) The effects of cooling to 5 degrees C and freezing and thawing on the ultrastructure of bull spermatozoa. J Reprod Fertil 56: 2338

Kakar SS, Anand SRA (1984) Transmission electron microscopic study of fresh and frozen buffalo spermatozoa. Indian J Exp Biol 22: 11-17

Khan MH, Nath KC, Naskar S, Deka BC, Kumae, C (2015) Electron microscopic studies of porcine sperm changes during freezing and post-thawing. Indian J Anim Sci 85: 723-728

Krogenaes A, Anderson B.K, Hafne Al, Engeland E (1994) Membrane alterations in bull spermatozoa after freezing and thawing and after in vitro fertilization. Acta Vet Scand 35: 17-26

Lessard C, Parent P, Leclerc P, Bailey JL, Sullivan R (2000) Cryopreservation Alters the Levels of the Bull Sperm Surface Protein P25b. J Androl 21: 700- 707

Li YH, Cai, KJ, Su L, Gaun M, He XC, Wang H, Kovacs A, Ji WZ (2005) Cryopreservation of cynomolgus monkey (Macaca fascicularis) spermatozoa in a chemically defined extender. Asian J Androl 7: 139-144

Lopez-Armengol MF, Jurado SB, Pelufo V, Eisen EG (2012) A quantitative ultramorphological approach for systematic assessment of sperm head regions: An example in rams. Cryobiol. 64: 223-234
Luque MCA, Bao SN (2006) Structural and ultrastructural characterization of zebu (Bos indicus) spermatozoa. Biocell 30: 1

Merino O, Aguaguina WE, Esponda P, Risopatrón J, Isachenko E, Isachenko V and Scnchez R (2015) Protective effect of butylated hydroxytoluene on sperm function in human spermatozoa cryopreserved vitrification technique. Andrologia 47: 186-93

Patel A, Saxena A, Swain DK, Yadav D, Yadav SS, Kumar A (2015) Effect of supplementation of butylated hydroxytoluene on post-thaw sperm viability, motility and membrane integrity of Hariana bulls. Vet World 8: 808-812.

Pesch, S, Bostedt H, Failing K, Bergmann M (2006) Advanced fertility diagnosis in stallion semen using transmission electron microscopy. Anim Reprod Sci 91: 285-298

Salamon S, Maxwell WMC (1995) Frozen storage of ram semen. Cause of low fertility after cervical insemination and methods of improvement. Anim Repord Sci 38: 1-36

Sharma M, Singh A (2019) Changes in Ultrastructure of Crossbred Bovine Spermatozoa in Butylated Hydroxytoluene Supplemented Semen. Int J Livest Res 9: 64-69

Tartaglionea CM, Ritta MN (2004) Prognostic value of spermatological parameters as predictors of in vitro fertility of frozen-thawed bull semen. Theriogenology 62: 1245-1252

Watson PF (1995) Recent developments and concepts in the cryopreservation of spermatozoa and the assessment of their post thawing function. Reprod Fertil Dev 7: 871-891

Yue A, Meng FJ, Jorgensen N, Ziebe S, Nyboe AA (1995) Sperm morphology using strict criteria after Percoll density separation. Hum Repord 10: $1781-1785$ 